\title{
Reconstruction of Socioeconomic Life Cave Habitation of Mesolithic in Karts Area "Bukit Bangkai", Tanah Bumbu, South Kalimantan: Archaeological Study of Mesolithic Industry and Kitchenmidden
}

\author{
$1^{\text {st }}$ Blasius Suprapta \\ Universitas Negeri Malang \\ Malang Indonesia \\ blasius.suprapta.fis.um@gmail.com
}

\author{
$2^{\text {nd }}$ Ulfatun Na'fiah \\ Universitas Negeri Malang \\ Malang Indonesia \\ diafa2@gmail.com
}

\author{
$3^{\text {rd }}$ Arief Subekti \\ Universitas Negeri Malang \\ Malang Indonesia \\ arief.subekti.fis@um.ac.id
}

\begin{abstract}
Based on the old paradigm of reconstruction of prehistoric human socio-economic life is based on technological conceptions, so that the reconstruction of the socio-cultural life of the prehistoric times is less humanistic and does not prioritize the human dimension. In reconstructing past human life including socio-economic life, in order to prioritize the human and humanist dimensions, using a new paradigm, namely is called the paradigm of the living livelihood system. In the context of this paradigm, the reconstruction of socio-economic life is divided into several stages. The stages in question are the stages of hunting and gathering food at a simple, advanced level, planting period and the bronze-iron age. Reconstruction of the socioeconomic life of mesolithic dwelling cave in Bukit Bangkai, South Kalimantan, entered the stage of advanced hunting and gathering. Reconstruction at this stage, based on the findings of the distribution of cave wall paintings, mesolithic industry and remains of foods in kitchenmidden. The newness of this research is to find the latest data on the stages of mesolithic culture in South Kalimantan mainly in the southeastern region of the Meratus Karts Mountains which have not been reported in previous studies. The findings of this study are expected to be able to complement the cultural process of a simple (paleolithik) hunting period to an advanced hunting and gathering period in South Kalimantan.
\end{abstract}

Keywords: life cave, kitchenmidden

\section{INTRODUCTION}

Karts area "Bukit Bangkai " is one of the karts in the Meratus Mountains in the Mentewe region, Tanah Bumbu, South Kalimantan. The karst area "Bukit Bangkai " consists of several karst hill clusters namely Bukit Liang Bangkai, Liang
Batu Ukir, Liang Susu, and Bukit Liang Jago [1]. In this paper we discuss the socio-economic life of the karst cave dwellers at the level of mesolithic culture around 6,000 years ago. The paradigm used to reconstruct the socio-economic life of the inhabitants of the cave in the karst area of "Bukit Bangkai" is to use a living livelihood approach [2]. Data and sources of data in the form of remains of stone tools, namely mesolithic tools, among others in the form of flakes tools, cores stones, and remainst of animals bone that accumulate in kitchenmidden. The two types of data can be found widely in a number of residential caves in the karst region "Bukit Bangkai " namely in Gua Liang Bangkail, Gua Liang Bangkai 2, Gua Liang Bangkail0, Ceruk Leang Bangkai 13, Gua Liang Batu Ukir, Gua Liang Susu and Ceruak Liang Susu 1, and Gua Liang Jago[3].

\section{METHOD}

The method of collecting data is surface survey of mesolithic data and distribution of food remains in kitchenmidden and depth observation of residential cave morphological conditions. Cave observation occupancy included cave height, cave humidity, cave direction in relation to sunlight, cave comfort, and cave placement in relation to water sources such as rivers and water reservoirs. These matters are related to the ecological approach, relying on the cave conditions of mesolithic [4].

The analyses are classification of mesolithic materials and classification of species animals, and zoological analysis of various types of species animals such as zoological analysis of 
shells or mollusks and various types of land animals. The analyses of mesolithic materials include morphological of stones tools and functional analysis of mesolithic materials, while the analysis of various types of molluskincludes the biological environment of the molluskand the biological environment of various types of land animals and their behavior [4]. The results of the analysis of mesolithic materials and zoological analysis of the remains of the mollusk and the remains of animal bones are closely related to the interpretation of the reconstruction of the socio-economic life of the cave dwellers in the karst area of Bukit Bangkai, Mentewe, Tanah Bumbu, South Kalimantan at mesolithic period around 6,000 years ago. The scope of the study of socio-economic life is related to the ways of choosing a dwelling cave, ways to huntings and gatherings in swamps and rivers, ways of reproduction of stone tools and ways of processing food resources [2].

\section{RESULTS AND DISCUSSION}

\section{A. Data Exposure}

\section{1) The morphology of residential cave}

The morphological of residential cave are the Gua Liang Bangkai 1, Gua Liang Bangkai 10, Gua Liang Batu Ukir Cave, Gua Liang Susu land Gua Liang Jago. The description of the morphology of the fifth cave of the residential cave are:

\section{a) Morphology of Gua Liang Bangkail}

Gua Liang Bangkai 1 is one part of the cave in Bukit Bangkailocated at the foot of the hill on the south side of the Bukit Bangkai. The morphological of the cave, which is the cave door facing west: N.270 ${ }^{\circ} \mathrm{E}$, the sun's intensity is very good, the ventilation of the cave is very good, allowing the cave room to be dry and not humid. The cave floor is higher than the surrounding surface, free from puddles, so the condition of the cave floor is very dry and not moist. The door part of the cave is protected by chunks of limestone, so the cave is safe to inhabit and avoid wild animal attacks. The cave floor is spacious, dry and not moist, so that it allows the intensity of activities in the cave room to be very high. The ceiling of the cave is high, forming a long niche, so that my room is protected from runoff, and this results in the entire room being dry, not humid and air circulation in very good condition. The position of the cave is adjacent to water sources and underground rivers. There are two niches and a very large, protected cave room. This kind of cave morphology allows the cave to be inhabited for a long time [3].

\section{b) Morphology of Gua Liang Bangkai 10}

Gua Leang Bangkai 10 is one of the Bukit Bangkaicaves located on the north side of Bukit Bangkai. The direction facing the cave to the north is N.0 ${ }^{\circ} \mathrm{E}$ and this allows the intensity of sunlight into the room of the cave very well. This cave is above the Ceruk 12 at the level of about $15 \mathrm{~m}$ from the floor of Ceruk 12 . The cave consists of 6 rooms and each cave room has a width of $10 \mathrm{~m}, 9.5 \mathrm{~m}, 13.5 \mathrm{~m}, 14.5 \mathrm{~m}, 8.5 \mathrm{~m}$ and $3 \mathrm{~m}$. The length of each cave room is $9 \mathrm{~m}, 11 \mathrm{~m}, 16.5 \mathrm{~m}, 17.5 \mathrm{~m}, 14 \mathrm{~m}$ and $4 \mathrm{~m}$. The floor condition of cave is very dry, the air circulation is very good, so the cave room is dry and not moist. The ceiling of the cave is a long and wide, allowing to avoid rainwater run off, so the cave room is very comfortable to inhabit. The position of the cave is adjacent to the water source, so that it allows abundant water availability. The cave floor is higher than the surrounding land, even above the cave space of Ceruk 12. This allows to avoid being attacked by wild animals and puddles, so it is suitable to be inhabited for a long time [3].

\section{c) Morphology of the Gua Liang Batu Ukir}

The Gua Liang Batu Ukiris located on a karts hill in the form of a blunt tower located on the east side of Bukit Bangkai, about $300 \mathrm{~m}$ away. On the Bukit Batu Ukirthere is the Gua Liang Batu Ukirin the form of shallow niches. The Gua Liang Batu Ukirfaces west namely N.275 ${ }^{\circ} \mathrm{E}$ and to the east N $90^{\circ}$ $\mathrm{E}$, so that throughout the day the Liang Batu Ukir in the form of dukes is exposed to sunlight. Based on this long morphology, the intensity of the entry of sunlight and air circulation in room caves is very good, this results in the room being dry and not moist. The condition of the cave floor is higher than the surrounding land surface, free from standing water, so the condition of the floor of the cave is dry and not moist. The spacious cave room extends to follow the path of the hillside and is dry and not humid. This kind of morphology allows the intensity of activities in a cave room to be high, so that it can be inhabited for a long time. The condition of the roof of the cave in the form of an elongated intersects half the foot of the hill, allowing the avoidance of cave space from runoff of rain and wind. This results in the condition of the room being dry, not humid, the air circulation is very good and the intensity of the sun's rays is maximal. From some of the cave's morphological criteria, the Gua Liang Batu Ukiris worth inhabiting in a long time.

On the other side of the cave room is divided into several shallow and multilevel niches, allowing the cave space to be occupied by several mesolithic community groups. The position of the Gua Liang Batu Ukiris adjacent to the water source namely the underground river. This allows abundant water availability and allows adequate food resources. The condition of shallow recesses at the foot of the Bukit Batu Ukiris easily accessible and the surrounding environment is in the form of swamp forest, allowing the availability of abundant food resources and herbs [3], [5].

\section{d) Morphology of Ceruk Liang Susus 1}

The Ceruk Liang Susus Iis at the northwestern edge of Bukit Leang Susu and this form is a narrow and shallow niche. Bukit Susu is not far from Bukit Batu Ukir, about 200 m away and between Bukit Batu Ukir and Bukit Liang Susu associated with underground rivers and swamp plains. The condition of Gua Liang Susu has experienced severe erosion due to 
underground river flow, so that my cave has been eroded. The cave that is still left as a residential cave is the Ceruk Liang Susu1. The Ceruk Liang Susu 1is a narrow and shallow niche, the niche door facing northwest namely N.320 ${ }^{\circ}$ E, thus allowing the sunlight to enter into the cave room. The cave floor is much higher than the surrounding ground, allowing the cave floor to be free of puddles. The walls of the cave and the ceiling of the cave are dry and not in a valley, so that it allows the cave room to be dry and not humid. The condition of the cave's ceiling is in the form of an elongated umbrella, thus allowing cave room to be free from runoff and rain gusts [3]

The cave room is in the form of a niche and several narrow aisles in dry and non-humid conditions. The existence of a cave is adjacent to a water source, namely an underground river and associated with swamp forest. This allows the cave to be inhabited for a long time, because of the abundant availability of water and food resources in the form of huntings animals and herbs in swamp forest areas [3], [5].

\section{e) Morphology of the Gua Liang Jago}

Gua Liang Jago is located at the foot of Bukit Jago in the form of a hill in the form of a blunt karst tower morphology and the Bukit Jago site located north of Bukit Bangkai, about $200 \mathrm{~m}$ away. Between Bukit Jago and Bukit Bangkai in the form of swamp forest and connected by an underground river. In the formof Gua Liang Jagoshallow alcove extends and the door of the cave leads to the northwest namely N.340 ${ }^{\circ} \mathrm{E}$, thus allowing the entensity of sunlight to enter the cave room. The condition of cave ventilation is very good, the air circulation in the room is maintained and good, so that it allows the condition of the room to be dry and not moist. The cave room is in the form of a wide niche, dry and not humid, allowing the intensity of activities in the cave room to be very high. The condition of the cave floor is much higher than the surrounding land surface, allowing my cave floor to be free of puddles. The condition of the cave's ceiling is an elongated umbrella, allowing the cave yard and cave room to be free from runoff of rain and wind. This kind of Gua Liang Jagomorphologycan be inhabited for quite a long time [3].

The location of the Gua Liang Jagois adjacent to water resources, namely an underground river that flows towards the Bangkai Hill and is located in a swamp forest area. These natural environmental conditions allow the position of caves to be close to water sources and food resources. The condition of the cave morphology and the condition of the cave's environment allowed Liang Jago cave to be inhabited for a long and long time [2], [3], [5].

Based on the description of the morphology of the caves mentioned above, it can be seen that the characteristics of residential caves in the Bukit Bangkai karst area are dry and non-humid cave rooms, sunlight intensity, good cultural fentillation intensity, dry cave floor and free from puddles, my room is easy reached, and the ceiling of the cave shaped an elongated umbrella sideways, so that the cave yard and my room were free from runoff of rain and wind. Cave placement is adjacent to water resources and swamp forests and the availability of food resources.

\section{2) The distribution of lithik tools}

The lithik tools in the form of tools of the mesolithic tradition consist of flake tools, flakes, scraper, corse stone, arrowheads and chopper. The following is a description of the distribution of lithic tools in each residential cave are.

\section{a) Distribution of lithik tools at the Sites of Gua Liang} Bangkai 1

Based on the research of the Archaeological Center of South Kalimantan in 2010 and 2012, namely the excavation box No. C.20, the distribution of lithik tools in the form of flakes, flakes tools, core stones in a very large accumulation. In the excavation box C.17, C.18 and C.18, it is known that the entensity of flake and flake tools findings is very large and this indicates that the Sites of Gua Leang Bangkai 1besides being used as a residential cave, it is also used as a workshop or manufacture of flakes tools [6]. As stated by [7], [8] flake tools, namely as cutting tools, scribblers, punches, shovels and arrowheads in hunting and gathering food.

Based on the morphological analysis of the tool it can be found that the residents of Gua Liang Bangkai 1 have used flake tools to exploit food resources, especially in terms of hunting and gathering food. Flake tools, arrowheads can be used to hunt animals, while flake tools in the form of flakes can be used as cutters for hunting animal and gathering. Flakes tools in the form of shavings are used to make hunting equipment made of wood and flake shale tools used as holes or levers [2].

b) Distribution of lithik tools at the Sites of Gua Liang Bangkai 10

As explained earlier, the morphology of the Sites of Gua Leang Bangkaiis above the Ceruk Bangkai 12 at an altitude of $15 \mathrm{~m}$ from the floor of the Ceruk Bangkai 12. Based on the surface survey, there have been no indications of the findings of the distribution of lithik tools [3]. Based on the results of research at the South Kalimantan Archaeological Center in 2014, at this site two individual human skeletons were found, so the site was categorized as a mesolithic burial site in relation to human cave dwellers in the karst area of Bukit Bangkai. Two individual human skeletons have been identified by the research team of the South Kalimantan Archeology Center on 2015. It is known that the identification of the sex of the human skeleton, which is female and based on the physical characteristics of the morphology, is included as a Mongoloid pollulation [9]. 


\section{Batu Ukir.}

\section{c) Distribution of lithik tools at the Sites of Gua Liang}

Based on surface surveys in sector 3, Gua Liang Batu Ukirfound the distribution of lithik tools such as flakes, flakes tools, point tools, and core stones [3]. The morphological features of flake tools are the same as those found in the excavation boxes C.17, C.18 and C.20 of the Sites of Gua Liang Bangkai 1. Thus there can be presumed suspicion that the Sites of Liang Batu Ukiris inhabited by the same human group as the group of residents of Gua Liang Bangkai 1 [10]. Based on the morphological characteristics, it can be stated that lithik tools the Sites of Gua Liang Batu Ukir are used as cutters, breakers, piercers, arrowheads and shearers. Especially for scrapers tools, it may be used to prepare tools made of wood for the interest of hunting ang gathering in swampland $[2,[7],[8]$.

\section{Susus 1 .}

\section{d) Distribution of lithik tools in the Sites of Ceruk Liang}

Based on the surface survey, on the site of Ceruk Liang Susu 1, only a few lithik tools such as flakes, flake tools and core stones were found. The morphology of the lithik tool is the same as the lithik tools at the Sites of Gua Liang Bangkai 1 and the Sites of Gua Liang Batu Ukir. For the clarity and accuracy of the distribution of lithik tools, the need for further research activities at the Sites of Ceruk Liang Susu 1 [3]. Jago

$$
\text { e) Distribution of lithik tools on the Sites of Gua Liang }
$$

Based on the excavation research box of the research team at the Archaeological Center of South Kalimantan in the year 2017, it is known that the distribution of lithik tools on this site is dominated by flake, flake tool, and drawstring tools made of andesite, flint and grit [10]. Some lithik devices show signs of fire. Based on surface survey, chopper made from limestone raw material was found. This tool is usually used to break animal bones and soft objects cutting tools such as wood and animal bones [8].

Of the types of lithik tools it is known that the function of shale tools is as a cutter, scribe, shaver and arrowhead. While the chopper is used as a beater or bone breaker for animals to retrieve the marrow. Based on the analyst of lithik tool function, it is known that the cave dwellers on the Sites of Gua Liang Jago are not much different from the cave dwellers on the Sites of Gua Liang Bangkai , Liang Batu Ukir and Ceruk Liang Susu 1 [3].

\section{3) The distribution of kitchenmidden}

Kichenmidden is the accumulation of food scraps resulting from hunting in the form of food scraps from land animals, water, swamps and food scraps from food gathering activities. Usually in the form of shells, carapace, bones of land animals and the remains of grains. The practice of analyzing kitchenmidden is to find out the types of hunting and gatherings, types of plants that are consumed by mesolithic humans, food diets as well as roaming hunting and ecological activities of hunting grounds. For this reason, it is very important to explain the distribution of kitchenmidden on all five residential cave sites in the Bukit Bangkai area. The distribution of kitchenmidden in each residential cave is as follows:

\section{Bangkai 1}

a) Spread of kitchenmidden at the Sites of Gua Liang

Based on the results of the land surface survey, kitchenmidden on the floor of Gua Liang Bangkai 1 is quite abundant and is dominated by the remains of invertebrate food in the form of freshwater molluscs consisting of the order of the order Tiaridae, Pupinidae, Limmaidae and Tiaridae. Gastropods of the order of Tiaridae, Pupinidae, Limmaidae and Tiaridae originated from the swamp environment especially in the rivers that cross the swamp area [11]. The food remains of the invertebrate were also found abundantly in the excavation activities of the South Kalimantan Archaeological Center team in the E. 15 excavation box and G.14 box. In the excavation box G.14 also found karapak testudinidae, a type of sea turtle from the river marshes and fish spines [6].

In addition to the leftovers from invertebrates also found food scraps from vertebrate animals in the excavation box C.17. Identification of food remains of vertebrate animals is known that the types of animals that accumulate in kitchenmidden consist of bovidae, vertebrates, bear nails, jaw bones, animal skull bones, ribs, locust feet, and some fragile bones. In the context of the findings of animal bones also found ocher, charcoal, ash and burned animal bones [6].

Based on the analysis of food debris accumulated in the kitchenmidden, it can be seen that the cave dwellers in Bukit Bangkai have consumed various types of food from the swamp environment, the river in the form of avertebrate animals namely Gastropod order Tiaridae, Pupinidae, Limmaidae and Tiaridae, freshwater turtles and various types of fish from swamp and river environments [12]. In addition, they have consumed various types of vertebrate animals such as bovidae, bears, monkeys and deer. The presence of charcoal findings, remnants of ash and burned bone signs, residents of Gua Liang Bangkai 1 have known fire, thus processing food is not directly eaten but first heated with fire [13].

\section{b) The spread of kitchenmiden at the Sites of Gua Liang Bangkailo \\ Based on the surface survey the distribution of} kitchenmidden is found on the surface of the cave floor in the form of leftovers from invertebrate animals namely Gastropod mollusks of the order Tiaridae, Pupinidae, Limmaidae and Tiaridae [13]. Thus the food scraps found in the Sites of Gua Leang Bangkai 10 are the same and one species with 
invertebrate food remains at the Sites of Gua Liang Bangkai 1 [11].

In the context of the burial site, in the excavation box around the frame R.2 there were also various remains of vertebrate bones and also remains of Gastropod: Tiaridae, Pupinidae, Limmaidae and Tiaridae [12] The findings of the kitchenmidden provide information that the inhabitants of the Gua Bukit Bangkai have consumed various species of invertebrates and vertebrates. Invertebrates are predominantly from swamps and rivers, while vertebarata animals are endemic animals that occupy swamp forest adjacent to the river flow. From the results of human skeletal pathology analysis, R.2, it can be seen that the inhabitants of the Gua Bukit Bangkai have also consumed the types of tubers that are very abundant, thriving in the environment of the karts area. Generally these tubers thrive on the edges and crevices of karst hills [11].

\section{c) Distribution of kitchenmidden on the Siteof Gua Liang Batu Ukir}

Based on the surface survey the distribution of kitchenmidden on the Sites of Gua Liang Batu Ukirwas found on the cave floor at sector 3 Liang Batu Ukir. Kitchenmidden consists of leftovers from invertebrate foods which consist of Gastroproda: Tiaridae, Pupinidae, Limmaidae and Tiaridae orders. In addition it is also a form of vertebrate animal remnants such as bovidae, aves type and the possibility of turtle carapace. To justify the findings of leftovers, it is necessary to conduct in-depth research on food scraps that accumulate in kitchenmidden [3]. The remains of the food scraps which accumulate in the kitchenmidden are mixed with the findings of lithic devices.

In accordance with the results of the determination of kitchenmidden consisting of food remains of invertebrates and vertebrates, it can be stated that the cave penguins of Liang Batu Ukir have consumed animals from the swamp and river environment. Besides that, they also consume vertebrate animals such as bovidae and other land animals from swamp forest environments. Based on the determination of food remnants in the form of invertebrates and vertebrates, it is suspected that the inhabitants of the cave of Liang Batu Ukir were the same group of residents as the cave residents of Liang Bangkai 1 . Susu 1

\section{d) Spread of kitchenmidden at the Site of Ceruk Leang}

Based on the surface survey, the distribution of kitchenmidden is found at the cave entrance of Ceruk Leang Susu1. Determine kitchenmidden in the form of food scraps from invertebrates, namely Gastropoda: Tiaridae order, Pupinidae, Limmaidae and Tiaridae. The distribution of kitchenmidden is found in limited quantities, therefore the need for further research is related to the distribution of kitchenmidden [3].

The analysis of the determination of food remains in kitchenmidden, it is thought that cave dwellers in the Leang Susu 1 basin have consonverted invertebrate animals from swamps and rivers. It is also possible to consume vertebrate animals from swamp forest environments. It is also possible to consume the type of tubers as well as the cave inhabitants of Gua Liang Bangkai 10. Jago

e) Spread kitchenmidden on The Sites of Gua Liang

Based on the surface survey, the distribution of kitchenmidden is found on the cave floor the Sites of Gua Liang Jago. The distribution of kitchenmidden in the form of food scraps consists of the remains of invertebrate food, namely class Gastropoda order Tiaridae, Pupinidae, Limmaidae and Tiaridae. The remains of food from invertebrate animals were also found by the Research Team of the South Kalimantan Archaeological Institute in.2017 in the TP 1 excavation box [10]. The findings of food debris accumulate with vertebrate animal bone fragments, animal teeth, lithic tools, ash and earthenware. Further research on the determination of kitchenmidden needs further research [3].

Based on the determination of food remains in kitchenmidden, it can be known that the residents of Gua Leang Jagohave consumed various types of invertebrates, especially the types of marshes of swamps and rivers. Besides that, it has consumed various types of land animals, especially land animals from swamp forest environments. Allegedly also has consumed various types of tubers that grow abundantly in the karst area of Bukit Jago, Bukit Bangkai and Bukit Liang Susu [3].

\section{B. Reconstruction of Socio-Economic Life of Residents of Mesolithic Residential Cave in Karts Area "Bukit Bangkai"} Tanah Bumbu, South Kalimantan

In accordance with the results of cave morphology analysis, functional analysis of flake tools, and analysis of the distribution of kitchenmidden, it can be reconstructed the socio-economic life of the inhabitants of the mesolithic cave in the karts area "Bukit Bangkai". Based on the findings of the human skeleton in the Gua Liang Bangkai 10, it can be stated that the cave inhabitants of the karts Bukit Bangkai area, Bukit Batu Ukir, Bukit Liang Susu and Bukit Jago are Mongoloid race humans. Thus the supporters of mesolithic culture in the karst area of Bukit Bangkai have a strong affiliation with supporters of mesolithic culture in Niah Cave, Serawak, Tengkorak Cave, Keboboh Cave, Liang Jon and Liang Ulin [14].

As explained earlier, socio-economic life revolves around the residential caveelection activities, ways of making tools, ways to catch hunter animals and gatherings, ways to gather 
food and ways to process food resources. Based on the analysis of morphological characteristics of Gua Liang Bangkai 1, Gua Liang Bangkai10, Gua Liang Batu Ukir, Ceruk Liang Susu 1 and Gua Liang Jago, it is known that the selection of residential caves is based on the intensity of sunlight into the cave room. This factor has caused the cave room to be dry and not moist. In addition, the factor of air fentilation, so that the change of air in my room continues, thus making the cave room dry and not humid. The factor of the extent of my room is also a consideration, because it relates to the intensity of activities in the room to be free. The height factor of the cave floor is also an important consideration, because residential caves must be free from standing water from the surrounding environment. The ceiling of the cave must be in the form of an extending to the side, because this resulted in the cave room and the courtyard being free from runoff of rain and wind. Another important consideration is that residential caves must be close to water sources and directly related to food resources, namely hunting animals and gathering.

Based on morphological analysis and distribution of mesolithic devices at Gua Liang Bangkai 1, Gua Liang Bangkai 10, Gua Liang Batu Ukir, Ceruk Liang Susu 1 and Gua Liang Jago, we can explain about the methods of making tools. From the analysis of the findings of the lithic devices at the Sites of Gua Liang Bangkai 1 and the Site of Gua Liang Batu Ukir, it is known that they may take certain raw materials from a certain location from the edge of the Mentewe River. The raw materials are transported to residential caves and in the edge of cave room, they carry out the intrusion of fragile humps to be transformed into various types of shale tools such as shale, piercing, drawstring and prospective arrowheads. Thus, as a place to live, I also functioned as a workshop sites. Thus it is not surprising at the Site of Gua Liang Bangkai 1and the Gua Liang Batu Ukirfound abundant flakes, flakes tools and core stones.

Based on the analysis of kitchenmidden distribution which is dominated by invertebrate food remnants, namely in the form of Gastropod the ordo of Tiaridae, Pupinidae, Limmaidae and Tiaridae, the remains of vertebrate bone, charcoal, and remnants of ash, it can be reconstructed in ways hunting and gathering food. Based on the quantity of Gastropoda class mollusks which are very abundant, the human inhabitants of the Bukit Bangkai karst cave area intensively carried out catching mollusks. This is because the types of mollusks of the ordo of Tiaridae, Pupinidae, Limmaidae and Tiaridae, are found to be very abundant in the swamp area which is on the banks of rivers around the karst hills and small lakes. How to catch invertebrate animals is done by picking it from the edge or river bed. Then it was brought into a residential cave, because in the kitchenmidden is found remains of ash and signs of familiarity with the fire, it is possible that the mollusk is boiled with water, by putting it in pieces of bamboo and then heating it with fire. The method of consuming snail meat is gouged out, this is because almost all the findings of the snail shell are not beaten.

In addition to catching various types of mollusks also do fishing and land turtles. Possible types of fish that live in swamps and brackish water turtles. Fish spines and turtle carapace were found in kitchen waste in the excavation box of G.14. Vertebarta animal catches are various types of land animals that live in swamp forest environments such as deer, bears, various birds, swamp swamps and insects such as grasshoppers. Food remnants related to this matter were found in the excavation box of G.14 Gua Liang Bangkai 1.

Food gathering activities based on a dietary food analysis on the human skeleton R.1 are known to have collected food from tubers. The method of concocting is by using a lever possible from wood that is shaved with a tip drawstring tool. The end drawstring tool was found abundantly at Sites of Gua Liang Bangkai 1 and sites of Gua Liang Batu Ukir. From the aforementioned description, the socio-economic activities of the residents of the caves of the karst area of Bukit Bangkai are hunting and gathering food, especially in the swamps, river banks and small lakes.

\section{CONCLUSION}

According to the results of cave morphology analysis, distribution of kitchenmiden, analysis of human skeletons, morphology analysis of lithic devices and functional analysis of lithik tools, it can be reconstructed about the socialeconomic life of cave dwellers in the karst region of Bukit Bangkai. Cave dwellers in the karst area of Bukit Bangkai are Mongoloid. They occupy the karst hills, which are wetlands of swamps alternating between small rivers. Socio-economic activities namely hunting animals in swamps and rivers and hunting activities are accompanied by food gathering activities, especially the types of tubers that grow abundantly on the slopes and valleys of the karst hills. Thus the cave dwellers in the Bukit Bangkai karst area are characterized by mesolithiic communities living in the karst environment of the wet swamp forest landscape.

\section{REFERENCES}

[1] Bemmelen, R. W. van, 1949, The Geology of Indonesia Vol. I. A, The Hague: Martinus Nijhoff

[2] Soejono, R. P., 1981, "Tinjauan Perkerangkaan Prasejarah Indonesia" in Aspek-Aspek ArkeologiIndonesia (Aspects of Indoensian Archeology) No. 5, Jakarta: Proyek Penelitian Purbakala

[3] Suprapta, Balsius, Ulfatun Nafi'ah and Arief Suberkti, 2019, Laporan Penelitian:Makna Lukisan DindingGua di Kawasan Bukit Bangkai, Mentewe, Tanah Bumbu, Kalimantan Selatan (not publication), Malang: Lembaga Penelitian dan Pengabdian Kepada Masyarakat, Universitas Negeri Malang

[4] Renfrew, Colin and Bahn, Paul, 2016, Archeology :Theory, Methods and Practice, London:Thames \& Hudson 
[5] Anonim, 2014, Kalimantan Selatan dalam Angka, Banjarmasin:BPS Kalimantan Selatan

[6] Bambang Sugiyanto 2012, Penelitian Situs Prasejarah Liang Bangkai, Kecamatan Mantewe, Kabupaten Tanah Bumbu, Provinsi Kalimantan Selatan Tahap IV (not publication), Banjar-baru:Balai Arkeologi Banjarmasin

[7] Braidwood, Robert J. , 1957, Prehistoric Men, Chicago: Chicago Natural History Museum

[8] Oakley, Kenneth P, 1972, Man The Tool Maker, Chicago: The University of Chicago Press

[9] Bambang Sugiyanto, Sofwan Noerwidi, Ulce Oktrivia and Sundoko, 2015, Penelitian Identifikasi Kubur pada Situs Liang Bangkai dan Liang Ulin, Kecamatan Mentewe, Kabupaten Tanah Bumbu, Kalimatan Selatan (tidak terbit), Banjarbaru: Balai Arkeologi Banjarmasin
[10] Bambang Sugiyanto et. al, 2017, Laporan Ekskavasi dan Survei Kawasan Karst di Wilayah Desa Dukuhrejo, Kecamatan Mentewe, Kabupaten Tanah Bumbu, Kalimantan Selatan (not publication), Banjarbaru:Balai Arkeologi Kalimantan Selatan

[11] Suprapta, Blasius, 2018, Makna Lukisan Dinding Gua Daerah Pangkep dalam Kehidupan Mesolithik:perpektif Semiotika-Charles S. Peirce, Yogyakarta: Penerbit PT Kanisius

[12] Robert, D. , Soemodihardjo, S. and Kastoro, S, 1982, Shallow Water Marine Molluscs of North-West Jawa, Jakarta: Lembaga Oseonogi Nasional, Lembaga Ilmu Pengetahuan Indonesia

[13] Hooijer, D. A. , 1950, Man and Other Mammals from Toalian Sites in South-Western Celebes, Amsterdam:Nort-Holland Publishing Comany

[14] Chazine, Jean-Michel dan Jean-George Ferrié, 2018. "Recen Archeological Discoveries in East Kalimantan, Indonesia" IPPA Bulletin 28, pp. 16-22 